Family and Empire 



\section{Family and Empire}

The Fernández de Córdoba and the Spanish Realm

\section{Yuen-Gen Liang}

$\overline{\text { PENN }}$

UNIVERSITY OF PENNSYLVANIA PRESS

PHILADELPHIA 
A volume in the Haney Foundation Series established in 1961 with the generous support of Dr. John Louis Haney.

Publication of this volume was aided by a grant from the Program for Cultural Cooperation Between Spain's Ministry of Culture and United States Universities.

Copyright (C) 20II University of Pennsylvania Press

All rights reserved. Except for brief quotations used for purposes of review or scholarly citation, none of this book may be reproduced in any form by any means without written permission from the publisher.

Published by

University of Pennsylvania Press

Philadelphia, Pennsylvania I9IO4-4II2

www.upenn.edu/pennpress

Printed in the United States of America on acid-free paper IO $\quad 9 \begin{array}{lllllllll} & 8 & 7 & 6 & 5 & 4 & 3 & 2 & \text { I }\end{array}$

Library of Congress Cataloging-in-Publication Data Liang, Yuen-Gen.

Family and empire : the Fernández de Córdoba and the Spanish realm / Yuen-Gen Liang.- - Ist ed.

p. cm.- (Haney Foundation series)

Includes bibliographical references and index.

ISBN 978-0-8122-4340-6 (hardcover : alk. paper)

I. Fernández de Córdoba family. 2. Córdoba (Spain: Province)-History. 3. Spain-History-Ferdinand and Isabella, I479-1516. 4. Spain-History-Charles I, I5161556. 5. Spain-History-Philip II, I556-I598. I. Title. II. Series: Haney Foundation series.

DP6o.F47L53 20II

$946.0092 ' 2-\mathrm{dc} 22$ 
To my friends 
